\title{
Markers Linked to Wheat Stem Rust Resistance Gene Sr11 Effective to Puccinia graminis f. sp. tritici Race TKTTF
}

\author{
Jayaveeramuthu Nirmala, Shiaoman Chao, Pablo Olivera, Ebrahiem M. Babiker, Bekele Abeyo, Zerihun Tadesse, \\ Muhammad Imtiaz, Luther Talbert, Nancy K. Blake, Eduard Akhunov, Michael O. Pumphrey, Yue Jin, \\ and Matthew N. Rouse
}

First, twelfth, and thirteenth authors: Cereal Disease Laboratory, United States Department of Agriculture-Agricultural Research Service (USDA-ARS), St. Paul, MN 55108; second author: Cereal Crops Research, USDA-ARS, Fargo, ND, 58102; third, twelfth, and thirteenth authors: Department of Plant Pathology, University of Minnesota, St. Paul 55108; fourth author: Small Grains and Potato Germplasm Research Unit, USDA-ARS, Aberdeen, ID 83210; fifth author: International Maize and Wheat Improvement Center (CIMMYT)-Ethiopia, Addis Ababa, Ethiopia; sixth author: Ethiopian Institute of Agricultural Research, Kulumsa Agricultural Research Center, Kulumsa, Ethiopia; seventh author: CIMMYT-Pakistan, Islamabad, Pakistan; eighth and ninth authors: Department of Plant Sciences and Plant Pathology, Montana State University, Bozeman 59717; tenth author: Department of Plant Pathology, Kansas State University, Manhattan 66506; and eleventh author: Department of Crop and Soil Sciences, Washington State University, Pullman, 99164.

Accepted for publication 27 May 2016.

\begin{abstract}
Nirmala, J., Chao, S., Olivera, P., Babiker, E. M., Abeyo, B., Tadesse, Z., Imtiaz, M., Talbert, L., Blake, N. K., Akhunov, E., Pumphrey, M. O., Jin, Y., and Rouse, M. N. 2016. Markers linked to wheat stem rust resistance gene Srl1 effective to Puccinia graminis f. sp. tritici race TKTTF. Phytopathology 106:1352-1358.

Wheat stem rust, caused by Puccinia graminis f. sp. tritici, can cause severe yield losses on susceptible wheat varieties and cultivars. Although stem rust can be controlled by the use of genetic resistance, population dynamics of $P$. graminis f. sp. tritici can frequently lead to defeat of wheat stem rust resistance genes. $P$. graminis f. sp. tritici race TKTTF caused a severe epidemic in Ethiopia on Ug99-resistant 'Digalu' in 2013 and 2014.

The gene $\operatorname{Sr} 11$ confers resistance to race TKTTF and is present in 'Gabo 56 '. We identified seven single-nucleotide polymorphism (SNP) markers linked to Sr11 from a cross between Gabo 56 and 'Chinese Spring' exploiting a 90K Infinium iSelect Custom beadchip. Five SNP markers were validated on a 'Berkut'/'Scalavatis' population that segregated for $\operatorname{Srl1}$, using KBioscience competitive allele-specific polymerase chain reaction (KASP) assays. Two of the SNP markers, KASP 6BL_IWB10724 and KASP_6BL_IWB72471, were predictive of $S r 11$ among wheat genetic stocks, cultivars, and breeding lines from North America, Ethiopia, and Pakistan. These markers can be utilized to select for SrII in wheat breeding and to detect the presence of SrII in uncharacterized germplasm.
\end{abstract}

Stem rust, caused by Puccinia graminis f. sp. tritici Erikss. \& Henning, can result in significant yield losses worldwide (Singh et al. 2015). Historically, this disease has threatened wheat since Biblical times (Chester 1946), causing famines and epidemics (Bushnell and Roelfs 1984). In the United States, P. graminis f. sp. tritici caused sporadic stem rust epidemics between 1900 and 1965 , resulting in wheat yield losses up to $56 \%$ across states such as North Dakota (Leonard and Szabo 2005). However, wheat stem rust has been effectively controlled in the United States for half a century by eliminating the alternate host barberry (Leonard and Szabo 2005) and growing early-maturing wheat cultivars with multiple sources of resistance (Kolmer et al. 1991). Despite these efforts, wheat stem rust remains a threat to the world's wheat production because of variability of virulence in the $P$. graminis $\mathrm{f}$. sp. tritici population, the ability of urediniospores to spread over long distances by wind, and an exponential reproduction capacity (Leonard 2001). Emergence of $P$. graminis f. sp. tritici race TTKSK (also known as Ug99) and its variants from Africa raised serious concern because several resistance genes deployed in commercial production are not effective against this

Corresponding author: M. N. Rouse; E-mail address: matthew.rouse@ars.usda.gov

*The $\boldsymbol{e}$-Xtra logo stands for "electronic extra" and indicates that two supplementary tables are published online.

http://dx.doi.org/10.1094/PHYTO-04-16-0165-R

This article is in the public domain and not copyrightable. It may be freely reprinted with customary crediting of the source. The American Phytopathological Society, 2016. race group (Jin et al. 2008, 2009; Pretorius et al. 2000; Wanyera et al. 2006). This not only heightened the attempts to develop cultivars with new sources of resistance but also intensified surveillance efforts, especially in Africa, to monitor the emergence and spread of new and existing virulent races. As a result, race TKTTF was identified to be the culprit behind the 2013-14 stem rust epidemics in Ethiopia (Olivera et al. 2015). This race was highly virulent on 'Digalu' wheat, which reached $50 \%$ of the bread wheat acreage in Ethiopia because of its resistance to stripe rust and to race TTKSK, the predominant $P$. graminis $\mathrm{f}$. sp. tritici race in Ethiopia until 2013 (Olivera et al. 2015). Though race TKTTF has been detected in Ethiopia since 2012, the 2013 epidemic is believed to be due to the narrow genetic background of stem rust resistance in widely planted Digalu, conferred by the single gene SrTmp, coupled with environmental conditions favoring stem rust.

Race TKTTF is genetically different from members of the Ug99 race group and it is avirulent to stem rust resistance genes $\mathrm{Srll}$, Sr24, and Sr31 (Olivera et al. 2015). Therefore, these genes could be deployed in combination with other genes to combat race TKTTF. Srl1 was originally mapped to chromosome 6B, more than 60 centimorgans (cM) away from the awn inhibitor gene $B 2$, which is near the centromere (Sears 1966) and believed to be linked to leaf rust resistance gene $L r 3$. Diversity Arrays Technology (DArT) markers that might be linked to Lr3 were suggested by Crossa et al. (2007). However, there is no strong evidence to substantiate the linkage of these DArT markers to either $\mathrm{Lr} 3$ or $\mathrm{Sr} 11$. Despite the knowledge of chromosome location, there are no diagnostic markers currently available to identify and select for $\operatorname{Sr} 11$ in wheat breeding. There is 
an urgent need to identify molecular markers closely linked to Srll to allow breeders to combine $S r 11$ with other resistance genes in wheat lines to provide resistance to race TKTTF. 'Gabo 56' wheat is known to possess $\mathrm{Srll}$ (Knott and Anderson 1956; Sears et al. 1957) and is resistant to race TKTTF. Gabo 56 also has $\mathrm{Sr} 9 \mathrm{~h}$ (Rouse et al. 2014), which confers resistance against race TTKSK. We assessed race TKTTF response in a Gabo 56/'Chinese Spring' recombinant inbred line (RIL) population and genotyped this population with a custom Infinium iSelect $90 \mathrm{~K}$ wheat singlenucleotide polymorphism (SNP) chip to (i) identify molecular markers that are closely linked to Srll from Gabo 56, (ii) convert the closely linked 90,000 SNP markers into a more breeder-friendly KBioscience competitive allele-specific polymerase chain reaction (KASP) assay platform, and (iii) validate their ability to postulate the presence of Srl1 in diverse germplasm from the United States, Canada, Ethiopia, and Pakistan.

\section{MATERIALS AND METHODS}

Plant materials. A population of $149 \mathrm{~F}_{4}$-derived RIL developed from a cross between Gabo 56 (CI 14035) and Chinese
Spring (CI 14108) (Rouse et al. 2014) was used for mapping of Sr11. The pedigree of Gabo 56 includes the source line of Srl1, 'Gaza'. Markers closely linked to $\mathrm{Sr} 11$ identified from the Gabo 56/Chinese Spring population were validated on 93 wheat accessions and $70 \mathrm{~F}_{6}$ RIL developed from a biparental cross between 'Berkut' and accession 'Scalavatis' (PI 210945). Berkut and the Berkut/ Scalavatis RIL were obtained from the Triticeae Coordinated Agricultural project. The 93 accessions were selected as follows: 27 genetic stock lines, including several near-isogenic lines, and 66 cultivars and breeding lines from North America, Pakistan, and Ethiopia. The list of lines used, with their origin and sources, are described in Supplementary Table S1. Cultivars and breeding lines were selected for Sr11-linked marker validation based on high or intermediate infection types in response to races TTKSK and TRTTF in addition to either high or Srll-characteristic low infection types in response to race TKTTF. The purpose of this selection procedure was to attempt to eliminate cultivars and breeding lines that possessed other major resistance genes that might mask the presence of Srll.

Stem rust assays. Seedling assays were conducted at the United States Department of Agriculture-Agricultural Research

TABLE 1. Primer types used for KBioscience competitive allele-specific polymerase chain reaction (KASP) assays for single-nucleotide polymorphism markers on chromosome arm 6BL derived from the 90K iSelect assay

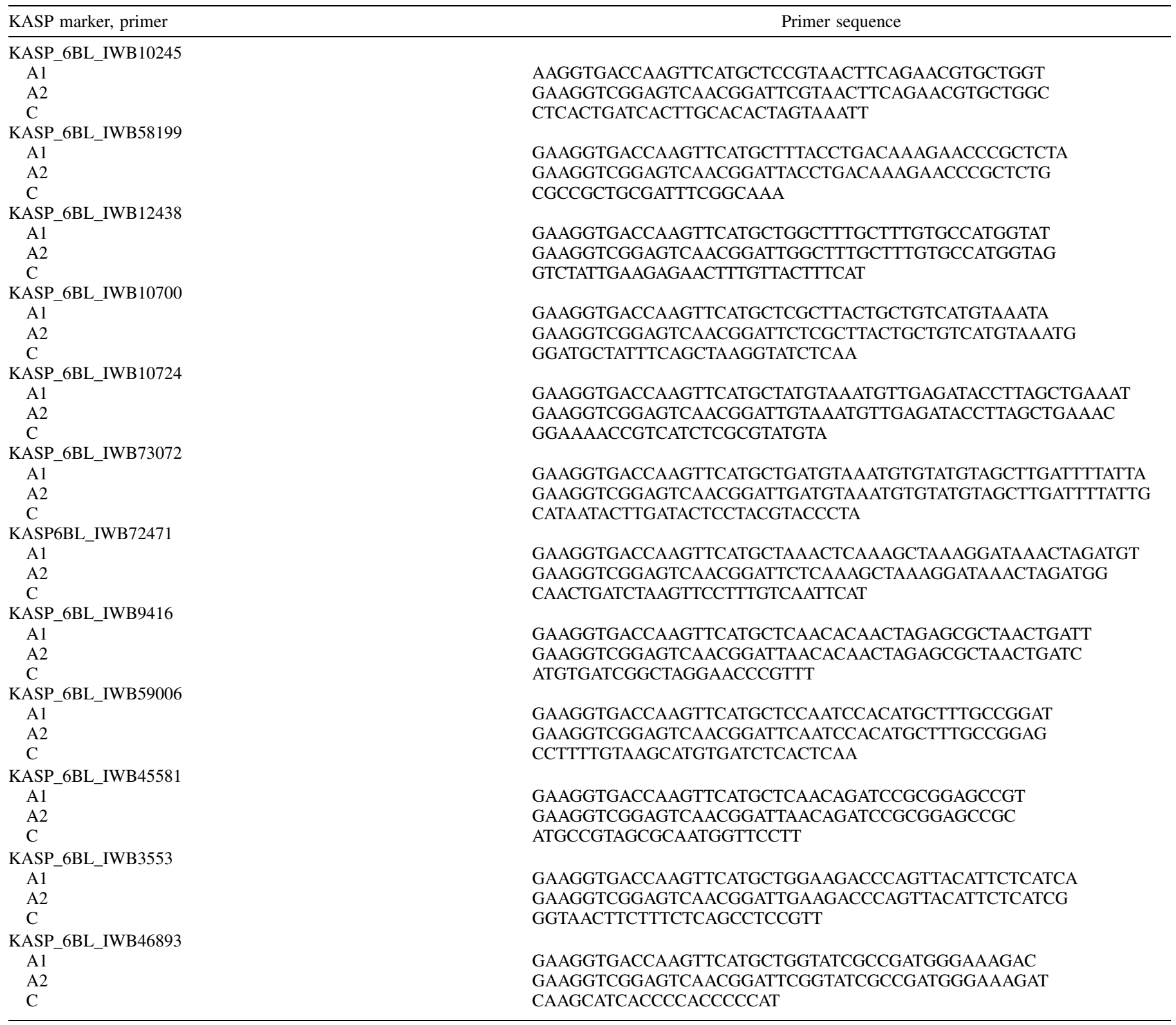


Service (USDA-ARS) Cereal Disease Laboratory and at a biocontainment facility at the University of Minnesota in St. Paul. The Gabo 56/Chinese Spring and Berkut/Scalavatis RIL populations were evaluated using $P$. graminis f. sp. tritici race TKTTF (isolate 13ETH18-1) according to previously described methods (Rouse et al. 2011). The additional wheat lines were evaluated with races TTKSK (isolate 04KEN156/04), TKTTF (isolate 13ETH18-1), and TRTTF (isolate 06YEM34-1). A subset of near-isogenic lines and breeding lines was also evaluated with two other U.S. races-RKRQC

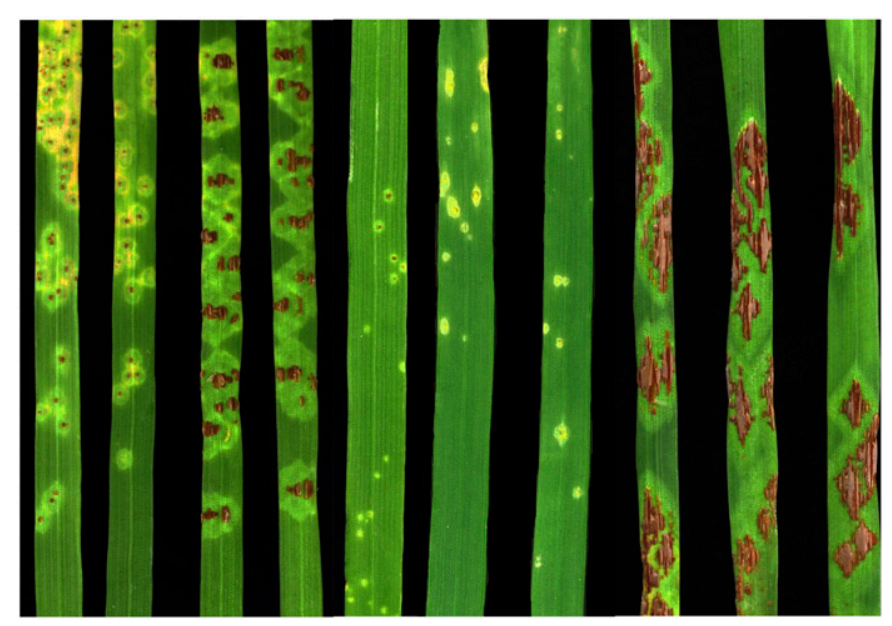

Fig. 1. Disease reaction of wheat accessions with and without $S r 11$ in response to Puccinia graminis f. sp. tritici race TKTTF at the seedling stage. Wheat accessions are represented by a single seedling leaf, arranged from left to right: Trident $(\operatorname{Sr} 11+S r 38)$, Gabo $56(\operatorname{Sr} 9 h+\operatorname{Sr} 11)$, ISr11-Ra $(S r 11)$, Berkut $(S r 11)$, Gaza $(S r 9 h+S r 11)$, Charter PI $210978(S r 9 h+$ Sr11), Timstein PI $16868(S r 9 h+S r 11)$, Chinese Spring, Scalavatis, and Bobin. (isolate 99KS76A-1) and RTQQC (isolate 04MN74-1)—which are avirulent and virulent to $S r 11$, respectively. Seedling infection types were determined 14 days after inoculation following the 0 -to-4 scale developed by Stakman et al. (1962). Infection types 0 to 2 were classified as "low" (incompatible interactions indicative of host resistance and pathogen avirulence) whereas infection types 3 to 4 were classified as "high" (compatible interactions indicative of host susceptibility). Symbols + and - were used to denote relatively larger or smaller pustule sizes, respectively, within each infectiontype classification. When two or more infection types were observed on the same leaf, both infection types were recorded, with the most prevalent infection type listed first. For example, infection type 33+ indicated that infection type 3 was most prevalent on a leaf and infection type 3+ was also present on the same leaf. Symbol / was used to separate different infection types observed on separate leaves of the same line, indicating a heterogeneous line. Two biological replicates of seedling screening were performed and a representative infection type was reported. For lines with an inconsistent infection type across the two replicates, a null phenotype was reported.

SNP genotyping and mapping. DNA was isolated from 10-day-old seedlings using a modified cetyltrimethylammonium bromide extraction method (Rouse et al. 2012) and resuspended in water. The amount and purity of DNA was determined using NanoDrop model ND-1000 (NanoDrop Products). DNA isolated from 149 RIL of the Gabo 56/Chinese Spring population was genotyped at the USDA-ARS Cereal Crops Research Unit, Fargo, ND with 90,000 gene-based SNP using a custom Infinium iSelect beadchip array and an iScanner, following the manufacturer's instructions (Illumina Inc.) (Wang et al. 2014). Allele calls were performed using Genome Studio software (v2011.1; Illumina Inc.). The SNP consensus map data were imported into Genome Studio software and alleles were called for codominant markers previously mapped to chromosome arm 6BL. Linkage maps

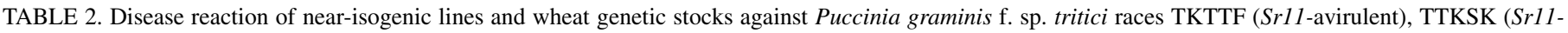

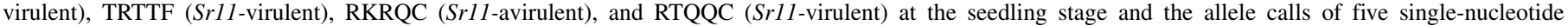
polymorphism markers associated with $\mathrm{Srl1}$ based on KBioscience competitive allele-specific polymerase chain reaction (KASP) assay

\begin{tabular}{|c|c|c|c|c|c|c|c|c|c|c|}
\hline \multirow[b]{2}{*}{ Lines } & \multicolumn{5}{|c|}{ Reactions by race ${ }^{a}$} & \multicolumn{5}{|c|}{ KASPb } \\
\hline & TKTTF & TTKSK & TRTTF & RKRQC & RTQQC & 1 & 2 & 3 & 4 & 5 \\
\hline LcSr11 $(S r 11)$ & 2 & $3+$ & $3+$ & $2-$ & $3+$ & $\mathrm{C}$ & A & G & $\mathrm{T}$ & $\mathrm{G}$ \\
\hline PdSr11Lee $(\operatorname{Sr} 11)$ & ;2- & $33+$ & $32+$ & $\ldots$ & $\ldots$ & $\mathrm{C}$ & A & $\mathrm{G}$ & $\mathrm{T}$ & G \\
\hline DK37 $(\operatorname{Sr} 11)$ & $22-$ & $3+$ & $3+$ & $2-$ & $3+$ & $\mathrm{C}$ & A & G & $\mathrm{T}$ & G \\
\hline Gabo $56(\operatorname{Sr} 9 h+\operatorname{Sr} 11)$ & $22-$ & $22-$ & $3+$ & ;2- & ;2- & $\mathrm{C}$ & $\mathrm{A}$ & $\mathrm{G}$ & $\mathrm{T}$ & G \\
\hline Berkut $(\operatorname{Sr} 11)$ & $22+$ & $3+$ & $33+$ & $2-$ & $3+$ & $\mathrm{C}$ & $\mathrm{H}$ & $\mathrm{T}$ & $\mathrm{T}$ & $\mathrm{G}$ \\
\hline ISr11-Ra $(\operatorname{Sr} 11)$ & $22+$ & $3+$ & $3+$ & $12-$ & $3+$ & $\mathrm{C}$ & A & G & $\mathrm{T}$ & $\mathrm{G}$ \\
\hline Trident $(\operatorname{Sr} 11+\operatorname{Sr} 38)$ & ;2- & $3+$ & $3+$ & $; 1-$ & $0 ; 1$ & $\mathrm{C}$ & A & G & $\mathrm{T}$ & $\mathrm{G}$ \\
\hline BtSr11Lee $(\operatorname{Sr} 11)$ & $22+$ & $3+$ & $3+$ & $; 21$ & $\ldots$ & $\mathrm{C}$ & A & $\mathrm{G}$ & $\mathrm{T}$ & G \\
\hline PdSr11Wld $(\operatorname{Sr} 11)$ & 0 & $3+$ & $3+$ & $0 ; 2-$ & $3+$ & $\mathrm{C}$ & A & $\mathrm{G}$ & $\mathrm{T}$ & G \\
\hline Gaza $(\operatorname{Sr} 9 h+\operatorname{Sr} 11)$ & $; 1$ & $11+$ & $3+$ & $; 1-$ & $11+$ & $\mathrm{C}$ & A & G & $\mathrm{T}$ & G \\
\hline Charter PI $158406(S r 9 h+S r 11)$ & $12-$ & 2 & $3+$ & ;12- & $2-$ & $\mathrm{C}$ & A & G & $\mathrm{T}$ & G \\
\hline Timstein CI $12347(S r 9 h+S r 11)$ & $12-$ & $22+$ & $3+$ & $2-$ & $22-$ & $\mathrm{C}$ & A & G & $\mathrm{T}$ & G \\
\hline Timstein PI $16868(S r 9 h+S r 11)$ & $1 ;$ & $22+$ & $3+$ & $2-$ & 2 & $\mathrm{C}$ & A & $\mathrm{G}$ & $\mathrm{T}$ & G \\
\hline Charter PI $210978(S r 9 h+S r 11)$ & 1 & 2 & $3+$ & $; 12-$ & $2-$ & $\mathrm{C}$ & A & $\mathrm{G}$ & $\mathrm{T}$ & G \\
\hline Charter PI $155430(S r 9 h+S r 11)$ & $; 12-$ & 2 & $3+$ & $0 ; 12 / ; 2$ & $2-$ & $\mathrm{C}$ & A & G & $\mathrm{T}$ & $\mathrm{G}$ \\
\hline Flevina $(\operatorname{Sr} 11)$ & $12-/ 3+$ & $3+$ & $3+$ & $0 ; 2-13+$ & $3+$ & $\mathrm{C}$ & A & G & $\mathrm{T}$ & G \\
\hline Kenya Farmer PI $187165(\operatorname{Sr} 11)$ & ;1/3- & $3+$ & $3+$ & $2-$ & 3 & $\mathrm{C}$ & A & G & $\mathrm{T}$ & $\mathrm{G}$ \\
\hline Kenya Farmer PI $29070($ Sr 11) & $0 ; 1$ & $3+$ & $3+$ & ;2- & $33+$ & $\mathrm{C}$ & A & G & $\mathrm{T}$ & G \\
\hline Lee $(\operatorname{Sr} 9 g+\operatorname{Sr} 11+\operatorname{Sr} 16)$ & $2-;$ & $3+$ & $3+$ & ;12- & $3+$ & $\mathrm{C}$ & A & $\mathrm{T}$ & $\mathrm{T}$ & $\mathrm{G}$ \\
\hline Yalta $(\operatorname{Sr} 11)$ & $12-$ & $3+$ & $3+$ & $12-$ & $3+$ & $\mathrm{C}$ & A & G & $\mathrm{T}$ & G \\
\hline Chinese Spring & $3+$ & $3+$ & $3+$ & $3+$ & $3+$ & $\mathrm{T}$ & $\mathrm{T}$ & $\mathrm{T}$ & $\mathrm{H}$ & $\mathrm{T}$ \\
\hline Baart & $3+$ & $3+$ & $3+$ & $3+$ & $3+$ & $\mathrm{T}$ & $\mathrm{T}$ & $\mathrm{T}$ & $\mathrm{C}$ & $\mathrm{T}$ \\
\hline LMPG-6 & $3+$ & $3+$ & $3+$ & $3+$ & $3+$ & $\mathrm{T}$ & $\mathrm{T}$ & $\mathrm{T}$ & $\mathrm{C}$ & $\mathrm{T}$ \\
\hline Little Club & $3+$ & $3+$ & $3+$ & $3+$ & $3+$ & $\mathrm{T}$ & $\mathrm{T}$ & $\mathrm{T}$ & $\mathrm{C}$ & $\mathrm{T}$ \\
\hline Scalavatis & $33+$ & $3+$ & $3+$ & $3+$ & $3+$ & $\mathrm{T}$ & $\mathrm{T}$ & $\mathrm{T}$ & $\mathrm{C}$ & $\mathrm{T}$ \\
\hline Line E & 4 & $3+$ & $3+$ & $3+$ & $3+$ & $\mathrm{T}$ & $\mathrm{T}$ & $\mathrm{T}$ & $\mathrm{C}$ & $\mathrm{T}$ \\
\hline Bobin & $33+/ ; 13-$ & $3+$ & $3+$ & $3+$ & $3+$ & $\mathrm{T}$ & $\mathrm{T}$ & $\mathrm{T}$ & $\mathrm{C}$ & $\mathrm{T}$ \\
\hline
\end{tabular}

a Symbol "..." indicates null phenotype reported for inconsistent reaction across replicates.

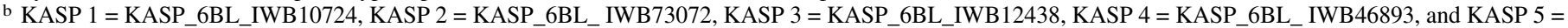
KASP_6BL_IWB72471. 
were constructed using Map Disto. The Kosambi mapping function was used to calculate genetic distance between markers (Kosambi 1943).

Marker validation using KASP assay platform. Bajgain et al. (2015) previously identified SNP markers associated with resistance to race TKTTF in a panel of 250 North American spring wheat cultivars and breeding lines. We selected five of these markers associated with resistance to race TKTTF with map positions on chromosome arm 6BL for conversion into KASP assays. In addition, seven markers from the Gabo 56/Chinese Spring linkage map were converted to KASP assays. We evaluated these 12 KASP-based SNP markers on Gabo 56/Chinese Spring and Berkut/ Scalavatis RIL populations and on $\operatorname{Sr} 11$ near-isogenic lines. Two markers most closely linked to race TKTTF resistance that were diagnostic for $\mathrm{Srll}$ in the near-isogenic lines were used in KASP assays to screen 66 breeding lines and cultivars from North America, Pakistan, and Ethiopia. The primer sequences designed for the KASP assays are provided in Table 1. Each KASP consisted of $50 \mathrm{ng}$ of DNA template and $5 \mu \mathrm{l}$ of $2 \times$ KASP buffer (LGC Genomics) and $0.14 \mu \mathrm{l}$ of primer mixture. Thermal cycling conditions were $94^{\circ} \mathrm{C}$ for $15 \mathrm{~min}$, followed by 10 cycles of touch-down polymerase chain reaction (PCR) of $94^{\circ} \mathrm{C}$ for $20 \mathrm{~s}$ and 65 to $57^{\circ} \mathrm{C}$ for $60 \mathrm{~s}$ (dropping $0.8^{\circ} \mathrm{C}$ per cycle), followed by 36 cycles of regular PCR of $94^{\circ} \mathrm{C}$ for $20 \mathrm{~s}$ and $57^{\circ} \mathrm{C}$ for $60 \mathrm{~s}$, followed by fluorescence reading at $20^{\circ} \mathrm{C}$. An additional three to nine cycles of PCR were added to obtain a good separation of clusters, if needed. Both thermal cycling and fluorescence reading were performed on an ABI Step One Plus Real Time PCR system. At least two replicates of each KASP assay were performed. If inconsistent results were observed between the two replicates, a third replicate was performed.

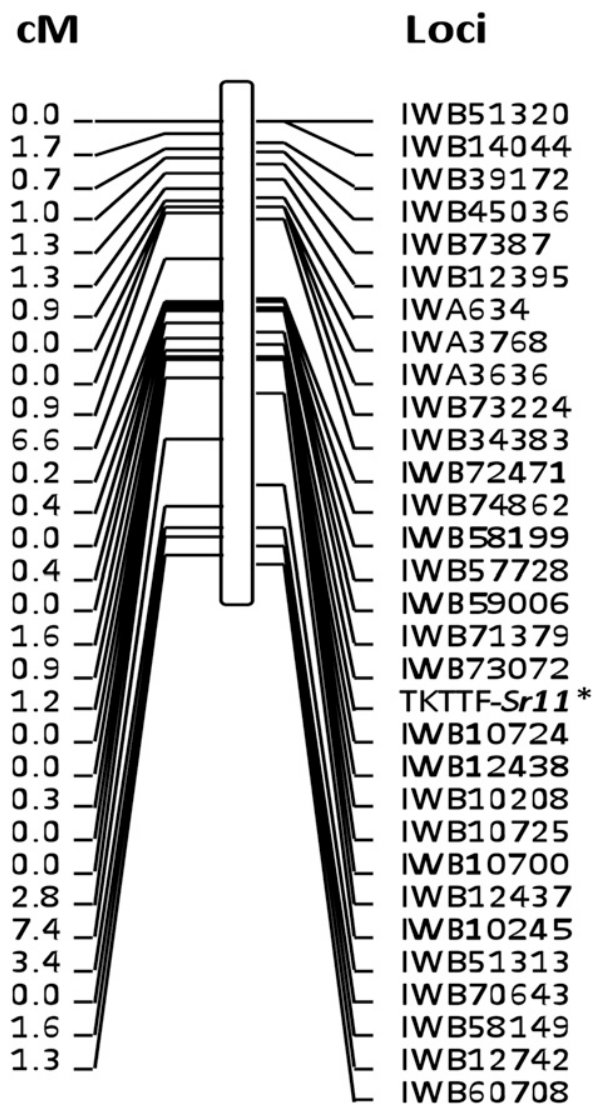

Fig. 2. Gabo 56/Chinese Spring genetic linkage map of chromosome arm 6BL including the race TKTTF resistance phenotype $(\mathrm{Sr} 11)$, constructed using an iSelect 90K Infinium assay. Values to the left of the marker names are the distances in centimorgans $(\mathrm{cM})$ generated using the Kosambi mapping function.

\section{RESULTS}

Stem rust assays. Gabo 56 exhibited an infection type of 22to 22+ whereas Chinese Spring exhibited an infection type of 3+ to race TKTTF (Fig. 1). The $\mathrm{F}_{4}$ lines of Gabo 56/Chinese Spring segregated for resistance to race TKTTF, with resistant plants exhibiting infection types $22-$ to $22+$ and susceptible plants exhibiting $33+$ to $3+$ infection types. Segregation of resistance did not significantly deviate from the expected ratio for a single gene $\left(\chi^{2}=1.2, P=0.55\right)$. Berkut displayed a ;2 infection type whereas Scalavatis exhibited a $3+$ infection type in response to race TKTTF (Fig. 1). The RIL population derived from Berkut/Scalavatis deviated from the expected 1:1 ratio for a single gene (46 resistant, 24 susceptible; $\chi^{2}=9.2, P=0.01$ ). However, Sr11-linked marker KASP_6BL_IWB10724 also deviated from the expected 1:1 ratio (45 Berkut allele, 22, Scalavatis allele; $\chi^{2}=7.7942, P=0.01$ ), indicating segregation distortion at this single locus. Both Gabo 56 and Berkut possessed infection-type patterns consistent with the presence of Srl1 (Table 2). We refer to the single-gene-mediated race TKTTF resistance from Gabo 56 and Berkut as $\mathrm{Sr} 11$.

Genetic linkage mapping. To identify molecular markers linked to $S r 11$, we generated a linkage map spanning $36.06 \mathrm{cM}$ with previously mapped chromosome arm 6BL markers identified by scoring the 90,000 SNP data from the Gabo 56/Chinese Spring population. Based on our data, resistance to race TKTTF clearly mapped to chromosome arm 6BL and was positioned between SNP markers IWB73072 (proximal) and IWB10724 (distal) (Fig. 2). The SNP names corresponding to the SNP identification numbers used are listed in Supplementary Table S2. These two flanking markers were linked to $\mathrm{Srll}$ at 0.7 - and $0.3-\mathrm{cM}$ distances, respectively. Seven markers were converted into KASP-based SNP markers (namely, IWB73072, IWB12438, IWB10724, IWB58199, IWB72471, IWB10245, and IWB10700) based on distinct clustering patterns. These markers were reevaluated on 149 Gabo 56/Chinese Spring RIL to generate a linkage map encompassing the region containing the gene resistant to TKTTF (Fig. 3). Two of these markers, IWB73072 and IWB59006, were also identified as linked to race TKTTF resistance in the association mapping study by Bajgain et al. (2015).

Evaluation of SNP markers to postulate the presence of Sr11. To identify potential markers that can discriminate lines with and without $\mathrm{Srl1}$, we evaluated a total of 12 KASP markers-7 derived from the Gabo 56/Chinese Spring linkage map and 5 derived from Bajgain et al. (2015) — on a set of near-isogenic lines and genetic stock lines. The allele calls for five of these markers along with their disease reaction to races TKTTF, TRTTF, TTKSK, RTQQC, and RKRQC are shown in Table 2. Lines resistant to races RKRQC and TKTTF but susceptible to races RTQQC, TTKSK, and TRTTF displayed an infection-type pattern consistent with the presence of $\operatorname{Srll}$ (Fig. 1). Of the 12 markers tested, 5 markers

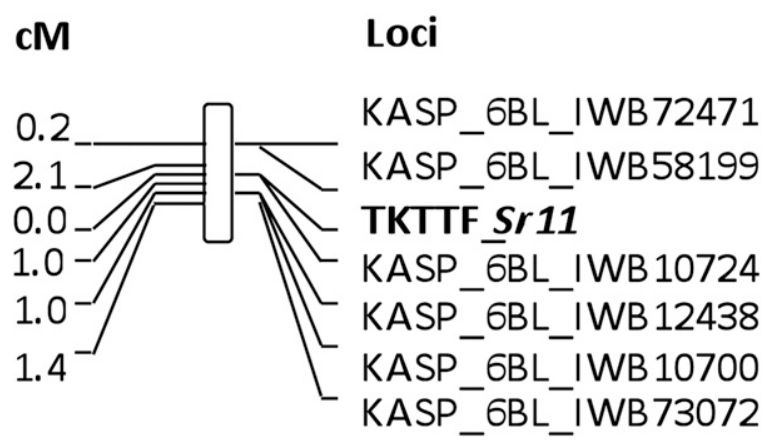

Fig. 3. Genetic linkage map of the $S r 11$ gene on chromosome arm 6BL constructed from Gabo 56/Chinese Spring $\mathrm{F}_{4}$ recombinant inbred lines using KBioscience competitive allele-specific polymerase chain reaction (KASP) assays. Values to the left of the marker names are the distances in centimorgans (cM) generated using the Kosambi mapping function. 
TABLE 3. Disease reaction of cultivars and breeding lines from Ethiopia, Pakistan, and North America against Puccinia graminis f. sp. tritici races TKTTF (Sr11-avirulent), TRTTF (Sr11-virulent), and TTKSK (Sr11-virulent) and allele calls of two single-nucleotide polymorphism markers using KBioscience competitive allele-specific polymerase chain reaction (KASP) assays

\begin{tabular}{|c|c|c|c|c|c|c|}
\hline \multirow[b]{2}{*}{ Lines, cultivars ${ }^{\mathrm{b}}$} & \multicolumn{3}{|c|}{ Reactions by race } & \multirow[b]{2}{*}{$G_{e n e}{ }^{c}$} & \multicolumn{2}{|c|}{$\mathrm{KASP}^{\mathrm{a}}$} \\
\hline & TKTTF & TRTTF & TTKSK & & 1 & 5 \\
\hline ETBW7872 & ;2- & $3+$ & $22-$ & Sr11 & $\mathrm{C}$ & G \\
\hline Tay & $12-$ & 2 & $33+$ & Sr11 & $\mathrm{C}$ & $\mathrm{H}$ \\
\hline CIMMYT-ETH-53 & $2-$ & $22+$ & $33+$ & Sr11 & $\mathrm{C}$ & G \\
\hline Digalu & $3+$ & $22+$ & $22-$ & No $\operatorname{Srl1}$ & $\mathrm{T}$ & $\mathrm{T}$ \\
\hline Kubsa & $33+$ & $3+$ & $3+$ & No $\operatorname{Sr} 11$ & $\mathrm{~T}$ & $\mathrm{~T}$ \\
\hline Kingbird & $33-;$ & 2 & $33-$ & No $\operatorname{Sr} 11$ & $\mathrm{~T}$ & $\mathrm{~T}$ \\
\hline Danda'a & $32+$ & $3+$ & $3+$ & No $\operatorname{Sr} 11$ & $\mathrm{~T}$ & $\mathrm{~T}$ \\
\hline CIMMYT-ETH-4 & 12 & $2-$ & $33+$ & Srl1 & $\mathrm{T}$ & $\mathrm{T}$ \\
\hline V-13318 & $2-$ & $3+$ & $3+$ & $\operatorname{Sr} 11$ & $\mathrm{C}$ & $\mathrm{G}$ \\
\hline V-13311 & $2-$ & $3+$ & $3+$ & $\operatorname{Sr} 11$ & $\mathrm{C}$ & $\mathrm{G}$ \\
\hline V-13324 & $2-$ & 3 & 3 & $\operatorname{Sr} 11$ & $\mathrm{C}$ & G \\
\hline 12FJ06 & 2 & 3 & $2+$ & Sr11 & $\mathrm{C}$ & G \\
\hline CCRI-50 & 2 & 3 & 3 & $\operatorname{Sr} 11$ & $\ldots$ & G \\
\hline QUEETA-2 & 2 & 3 & 3 & Sr11 & $\mathrm{C}$ & $\ldots$ \\
\hline NIA-9/5 & 2 & $3-$ & 3 & Srl1 & $\mathrm{C}$ & G \\
\hline DANI-16 & $2-;$ & $3+$ & 2 & Sr11 & $\mathrm{C}$ & G \\
\hline DN-93 & $2-$ & $3+$ & 4 & Sr11 & $\mathrm{C}$ & G \\
\hline DANI-17 & $3+$ & 23 & 3 & No $\operatorname{Sr} 11$ & $\mathrm{H}$ & $\mathrm{H}$ \\
\hline RCA-1 & $3+$ & 2 & 3 & No $\operatorname{Sr} 11$ & $\mathrm{~T}$ & $\mathrm{~T}$ \\
\hline 99172 & $3+$ & 2 & 3 & No $S r 11$ & $\mathrm{~T}$ & $\mathrm{~T}$ \\
\hline PR-106 & $3+$ & 2 & 3 & No $S r 11$ & $\mathrm{~T}$ & $\mathrm{~T}$ \\
\hline H0900081 & ;2- & $33+$ & $3+$ & Sr11 & $\mathrm{C}$ & G \\
\hline Macon & ;2- & $22-$ & $3+$ & Sr11 & $\mathrm{C}$ & $\mathrm{H}$ \\
\hline Scarlet & ;2- & $3+$ & $3+$ & Sr11 & $\mathrm{C}$ & G \\
\hline WA8034 & ;2- & $3+2$ & $3+$ & Sr11 & $\mathrm{C}$ & G \\
\hline 9248 & ;2- & $22+$ & $3+$ & Sr11 & $\mathrm{C}$ & G \\
\hline Berkut & $22+$ & $22+$ & $3+$ & Sr11 & $\mathrm{C}$ & G \\
\hline Alturas & $12-$ & $33+$ & $3+$ & $\operatorname{Sr} 11$ & $\mathrm{C}$ & $\mathrm{T}$ \\
\hline Cataldo & ;2- & $33+$ & $3+$ & Sr11 & $\mathrm{C}$ & $\mathrm{T}$ \\
\hline 9247 & $; 2$ & -2 & $3+$ & Sr11 & $\mathrm{T}$ & $\mathrm{T}$ \\
\hline SD4215 & $12-$ & $33+$ & $3+$ & Sr11 & $\mathrm{T}$ & $\mathrm{T}$ \\
\hline WA8016 & ;2- & $3+$ & $3+$ & Sr11 & $\mathrm{C}$ & $\ldots$ \\
\hline UC1551 & $33+$ & $22+$ & $3+$ & No $\operatorname{Sr} 11$ & $\mathrm{~T}$ & $\mathrm{~T}$ \\
\hline CDC Utmost & $33+$ & $3+$ & $3+$ & No $\operatorname{Sr} 11$ & $\mathrm{~T}$ & $\mathrm{~T}$ \\
\hline HR07005-3 & $33+$ & $3+$ & $3+$ & No $\operatorname{Sr} 11$ & $\mathrm{~T}$ & $\mathrm{~T}$ \\
\hline Kelse & $33+$ & $; 2-$ & $3+$ & No $\operatorname{Sr} 11$ & $\mathrm{~T}$ & $\mathrm{~T}$ \\
\hline Tara2002 & $3+$ & $22 / 33+$ & $3+$ & No $S r 11$ & $\ldots$ & $\mathrm{T}$ \\
\hline WA8123 & $33+$ & $22-$ & $3+$ & No $S r 11$ & $\mathrm{~T}$ & $\mathrm{~T}$ \\
\hline 9228 & $3+$ & $22-$ & $3+$ & No $\operatorname{Sr} 11$ & $\mathrm{~T}$ & $\mathrm{~T}$ \\
\hline 9241 & $33+$ & $22+$ & $3+$ & No $S r 11$ & $\mathrm{~T}$ & $\mathrm{~T}$ \\
\hline 9260 & $33+$ & $3+$ & $3+$ & No $S r 11$ & $\mathrm{~T}$ & $\ldots$ \\
\hline Jubilee & $3+$ & $3+$ & $3+$ & No $\operatorname{Sr} 11$ & $\mathrm{~T}$ & $\mathrm{~T}$ \\
\hline Lolo & $3+$ & 2 & $3+$ & No $\operatorname{Sr} 11$ & $\mathrm{~T}$ & $\mathrm{~T}$ \\
\hline Summit 515 & $33+$ & $33+$ & $3+$ & No $\operatorname{Sr} 11$ & $\mathrm{~T}$ & $\ldots$ \\
\hline Blanca Grande 515 & $3+$ & $3+/ 2$ & $3+$ & No $\operatorname{Sr} 11$ & $\mathrm{~T}$ & $\mathrm{~T}$ \\
\hline UC1603 & $3+$ & $3 / 22+$ & $3+$ & No $\operatorname{Sr} 11$ & $\mathrm{~T}$ & $\mathrm{~T}$ \\
\hline UC1554 & $33+$ & $3 / 22+$ & $3+$ & No $\operatorname{Sr} 11$ & $\mathrm{~T}$ & $\mathrm{~T}$ \\
\hline UC1599 & $33-$ & $33+$ & $3+$ & No $S r 11$ & $\mathrm{~T}$ & $\mathrm{~T}$ \\
\hline UC1601 & $33+$ & $33+/ 2+$ & $3+$ & No $\operatorname{Sr} 11$ & $\mathrm{~T}$ & $\mathrm{~T}$ \\
\hline UC1602 & $3+$ & 2 & $3+$ & No $\operatorname{Srl1}$ & $\mathrm{T}$ & $\mathrm{T}$ \\
\hline UC1616 & $3+$ & 2 & $3+$ & No $\operatorname{Sr} 11$ & $\mathrm{C}$ & $\mathrm{T}$ \\
\hline $10013-1$ & $33+$ & $22-$ & $3+$ & No $\operatorname{Sr} 11$ & $\mathrm{~T}$ & $\mathrm{~T}$ \\
\hline UC1683 & $33+$ & 2 & $3+$ & No $\operatorname{Sr} 11$ & $\mathrm{~T}$ & $\mathrm{~T}$ \\
\hline $10014 / 7$ & $33+$ & $33+$ & $3+$ & No $\operatorname{Sr} 11$ & $\mathrm{~T}$ & $\mathrm{~T}$ \\
\hline RIL203 & $33+$ & ;2- & $3+$ & No $\operatorname{Srl1}$ & $\mathrm{T}$ & $\mathrm{T}$ \\
\hline RIL 29 & $33+$ & $22-$ & $3+$ & No $\operatorname{Sr} 11$ & $\mathrm{~T}$ & $\ldots$ \\
\hline SD4218 & 3 & $3+$ & $3+$ & No $S r 11$ & $\mathrm{~T}$ & $\mathrm{~T}$ \\
\hline WhiteBird & $33+$ & $3+$ & $3+$ & No $\operatorname{Sr} 11$ & $\mathrm{~T}$ & $\mathrm{~T}$ \\
\hline AC Andrew & $33+$ & $3+$ & $3+$ & No $S r 11$ & $\mathrm{~T}$ & $\mathrm{~T}$ \\
\hline Selkirk & $3+$ & $3+$ & $3+$ & No $S r 11$ & $\mathrm{~T}$ & $\mathrm{~T}$ \\
\hline Park & $33+$ & $3+$ & $3+$ & No $S r 11$ & $\mathrm{~T}$ & $\ldots$ \\
\hline Marquis & $33+$ & $3+$ & $3+$ & No $S r 11$ & $\mathrm{~T}$ & $\mathrm{~T}$ \\
\hline МТ0945 & $33+$ & 2 & $3+$ & No $S r 11$ & $\mathrm{~T}$ & $\ldots$ \\
\hline Garnet & $3+$ & $3+$ & $3+$ & No $\operatorname{Sr} 11$ & $\mathrm{~T}$ & $\mathrm{G}$ \\
\hline UI Pettit & $33+$ & $3+/ 22+$ & $3+$ & No $\operatorname{Sr} 11$ & $\mathrm{C}$ & $\mathrm{T}$ \\
\hline MT1053 & $33+$ & $3+$ & $3+$ & No $S r 11$ & $\mathrm{C}$ & $\mathrm{T}$ \\
\hline
\end{tabular}

a KASP 1 = KASP_6BL_IWB10724, KASP 5 = KASP_6BL_IWB72471, and symbol “..." indicates null allele.

b CIMMYT = International Maize and Wheat Improvement Center.

c Gene postulation.
(KASP_6BL_IWB73072, KASP_6BL_IWB72471, KASP_6BL_ IWB10724, KASP_6BL_IWB46893, and KASP_6BL_12438) were able to discriminate the wheat lines based on presence or absence of Sr11, with few exceptions (Table 2). Two KASP markers originating from the Gabo 56/Chinese Spring linkage map (KASP_6BL_IWB10724 and KASP_6BL_IWB72471) were found to clearly discriminate the lines with and without $\mathrm{Srll}$ (Table 2).

Validation of two $\mathrm{Sr} 11$-linked SNP markers on diverse germplasm. Markers KASP_6BL_IWB10724 and KASP_6BL_ IWB72471 were subsequently evaluated on 66 selected breeding lines from Ethiopia, Pakistan, and North America (Table 3). Of these 66 lines, 14 possessed the $S r 11$ alleles, 34 possessed the nonSrl1 alleles, and 14 possessed mixed alleles for the two markers or heterozygous alleles. Of the 14 lines with the Sr11-alleles, all displayed infection-type patterns consistent with the presence of Sr11. Of the 34 lines with the non-Srl1 alleles, 31 displayed infection-type patterns consistent with the absence of Srl1, though 3 displayed $\operatorname{Srll}$ infection-type patterns.

Validation of Sr11-linked SNP markers in the Berkut/ Scalavatis population. Five SNP markers were found to be polymorphic between Berkut and Scalavatis. These markers were evaluated on $70 \mathrm{~F}_{6} \mathrm{RIL}$ from Berkut/Scalavatis and the data generated were used to make a linkage map (Fig. 4). KASP_6BL_IWB10724 cosegregated with $\mathrm{Sr} 11$ while KASP_6BL_IWB46893 was positioned $0.3 \mathrm{cM}$ distal to $\mathrm{Sr} 11$. Marker KASP_6BL_IWB58199, though polymorphic, was not linked to the race TKTTF phenotype.

\section{DISCUSSION}

Segregation of resistance and linked markers revealed that a single resistance gene conferred resistance to $P$. graminis $\mathrm{f}$. $\mathrm{sp}$. tritici race TKTTF in both Gabo 56 and Berkut. We mapped resistance to race TKTTF to chromosome arm 6BL (Fig. 2). The map location of resistance to race TKTTF is in agreement with the location of Srl1 (Sears 1966). Two markers (KASP_ 6BL_IWB10724 and KASP_6BL_IWB72471) that were linked to $\mathrm{Srll}$ in two mapping populations were further validated by haplotype analysis of diverse germplasm. The KASP_6BL_IWB10724 and KASP_6BL_IWB72471 markers accurately predicted the presence of Srl1. The presence of additional unknown genes might explain why three lines possessed the $S r 11$ phenotype but the nonSr11 marker haplotype. Alternatively, recombination may have separated $\mathrm{Sr} 11$ from the $\mathrm{Sr} 1 \mathrm{l}$-linked SNP marker haplotypes in these lines.

The Srl1-linked SNP markers predicted the presence of $S r l 1$ in 'Trident' wheat (Table 2) that was previously used as a stem rust differential line for detecting virulence or avirulence of $P$. graminis f. sp. tritici isolates in response to $\operatorname{Sr} 38$ (Olivera et al. 2012) although, initially, the source of $\operatorname{Sr} 38$, 'VPM1', was used as the differential for Sr38 (Jin et al. 2008). Screening race TKTTF resulted in a low infection type to Trident (2-) and a high infection

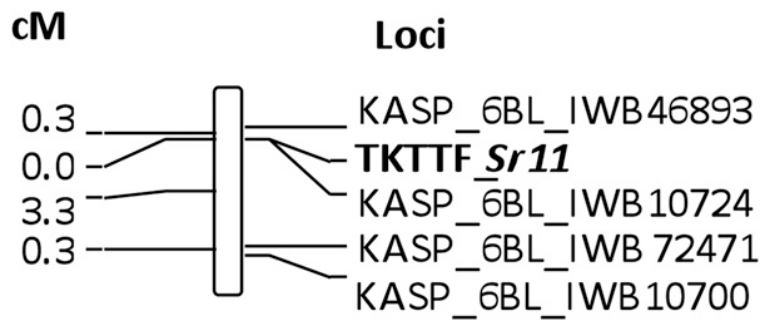

Fig. 4. Genetic linkage map of the $S r 11$ gene on chromosome arm 6BL from Berkut/Scalavatis $\mathrm{F}_{6}$ recombinant inbred lines using KBioscience competitive allele-specific polymerase chain reaction (KASP) assays. Values to the left of the marker names are the distances in centimorgans $(\mathrm{cM})$ generated using the Kosambi mapping function. 
type to VPM1 (3-), which indicated that Trident has Srll in addition to $\operatorname{Sr} 38$ (Olivera et al. 2015). These data suggest that $P$. graminis f. sp. tritici race analyses should avoid the use of Trident as a differential line because both $\mathrm{Sr} 11$ and $\mathrm{Sr} 38$ are present.

Assessing $\operatorname{Srll}$ genetic stocks with multiple $P$. graminis f. sp. tritici isolates, races, and SNP markers not only confirmed the linkage of SNP markers to Srll but also elucidated the source of $\mathrm{Sr} 9 \mathrm{~h}$ and the relationship between $\mathrm{Sr} 9 \mathrm{~h}$ and SrCharter. Varieties previously characterized as possessing $\mathrm{Sr} 11$ such as 'Timstein' and 'Charter' (Knott and Anderson 1956; Luig and Watson 1965) also possessed resistance to Srll-virulent races TTKSK and RTQQC (Table 2). The pedigree of Gabo 56 includes Timstein and Sr11 source Triticum turgidum var. durum Gaza: Timstein/'Kenya 58'// Gabo. The pedigree of Gabo is 'Bobin sel.'/Gaza//'Bobin'. Though the pedigree of Timstein has been reported as 'Steinwedel'/ T. timopheevii, multiple studies suggest that Timstein was actually derived from a cross between Bobin and Gaza (Boasso and Levine 1951; Levine et al. 1951; Rouse et al. 2014; Watson and Stewart 1956). Susceptibility of Kenya 58 and Bobin to race TTKSK combined with the results of resistance of Gabo, Gaza, and Timstein to race TTKSK (Rouse et al. 2014) (Table 2) suggest that $\mathrm{Sr} 9 \mathrm{~h}$ originates from durum Gaza. Resistance of Gaza, Timstein, and Gabo 56 not only to $S r 11$-avirulent race RKRQC but also to $S r 11$ virulent race RTQQC suggests that $S r 9 h$ confers resistance to North American race RTQQC. Though Charter was previously demonstrated to possess Srll (Luig and Watson 1965), Charter possessed resistance to isolates of $P$. graminis $\mathrm{f}$. sp. tritici that could not be explained by $\mathrm{Sr} 11$ alone (Luig 1983). This led researchers in India to include Charter as a differential line (Nagarajan et al. 1986) and led to the temporary designation of a second stem rust resistance gene in Charter as SrCharter (McIntosh et al. 1995). We observed Charter to possess the same infection-type pattern as Gabo 56, Timstein, and Gaza, suggesting that Charter possesses $\mathrm{Sr} 9 \mathrm{~h}$ in addition to $\mathrm{Sr} 11$ (Table 2). Charter was developed in New South Wales, similar to Gabo and Timstein. Similar to Sr9h, SrCharter avirulence in isolates virulent to $\mathrm{Srll}$ was detected in both North America and Kenya (Luig 1983). Though not definitively demonstrated by these data, the available evidence is consistent with the hypothesis that SrCharter and $\mathrm{Sr} 9 \mathrm{~h}$ are the same gene.

Srll is present in a number of U.S., Australian, Kenyan, and International Maize and Wheat Improvement Center cultivars (Roelfs and McVey 1979). Virulence to Srll is present in the United States (Roelfs et al. 1991), Australia (Zwer et al. 1992), South Africa (Le Roux and Rijkenberg 1987), Canada (Harder and Dunsmore 1990), and North Africa (Huerta-Espino 1992; Singh et al. 2015). This gene was highly effective when first deployed in Australia but its widespread use resulted in an increase in virulence frequency and, subsequently, the $P$. graminis $\mathrm{f}$. sp. tritici population became fixed for virulence to $\mathrm{Srll}$ in Australia. Though $\mathrm{Srl1}$ has been defeated by several $P$. graminis f. sp. tritici races throughout the world, it may be a valuable resistance gene for particular race groups of $P$. graminis f. sp. tritici. The current situation in Ethiopia highlights the importance of $\operatorname{Srl1}$, which can be exploited by breeding programs to combat race TKTTF epidemics. The unusual occurrence of the race TKTTF epidemic may be due to the widespread use of $\mathrm{Sr} 11$ in breeding programs throughout the world, making many deployed wheat varieties resistant to race TKTTF. Srll was transferred to spring wheat lines from Gaza durum wheat. The SNP marker haplotype predictive of $\mathrm{Srl} 1$ was conserved in Gaza (Table 2), further validating the utility of the markers. The KASP assay-based markers developed for $\mathrm{Sr} 11$ in this study could be used for at least three methods in selecting for stem rust resistance in the United States and around the world: (i) to select for wheat lines with $\mathrm{Srl1}$ in order to select for resistance to race TKTTF and other $S r 11$-avirulent races, (ii) to postulate the presence or absence of $\mathrm{Srll}$ in uncharacterized germplasm, and (iii) the markers could be used in combination with field studies to select for wheat lines without $S r 11$ but with adult plant resistance.

\section{ACKNOWLEDGMENTS}

Funding for this research was provided by USDA-ARS Appropriated Project 5062-21220-021-00, USDA-ARS National Plant Disease Recovery System, USDA-ARS Pakistan Wheat Production Enhancement Program, USAID Feed the Future, the Durable Rust Resistance in Wheat project, and the National Research Initiative Competitive Grant 2011-68002-30029 (TriticeaeCAP) from the USDA National Institute of Food and Agriculture. We thank the University of Minnesota Supercomputing Institute for computational support. Mention of a trademark, vendor, or proprietary product does not constitute a guarantee or warranty of the product by the USDA and does not imply its approval to the exclusion of other product or vendors that also may be suitable.

\section{LITERATURE CITED}

Bajgain, P., Rouse, M. N., Bulli, P., Bhavani, S., Gordon, T., Wanyera, R., Njau, P. N., Legesse, W., Anderson, J. A., and Pumphrey, M. O. 2015. Association mapping of North American spring wheat breeding germplasm reveals loci conferring resistance to Ug99 and other African stem rust races. BMC Plant Biol. 15:249.

Boasso, C. S., and Levine, M. N. 1951. Leaf rust of wheat, Puccinia rubigovera tritici in Uruguay. Phytopathology 41:736-741.

Bushnell, W. R., and Roelfs, A. P. eds. 1984. The Cereal Rusts, Vol. 1. Origins, Specificity, Structure, and Physiology. Academic Press, Orlando, FL.

Chester, K. 1946. The Nature and Prevention of the Cereal Rusts as Exemplified in the Leaf Rust of Wheat. Chronica Botanica, Waltham, MA.

Crossa, J., Burgueno, J., Dreisigacker, S., Vargas, M., Herrera-Foessel, S. A., Lillemo, M., Singh, R. P., Trethowan, R., Warburton, M., Franco, J., Reynolds, M., Crouch, J. H., and Rodomiro, O. 2007. Association analysis of historical bread wheat germplasm using additive genetic covariance of relatives and population structure. Genetics 177:1889-1913.

Harder, D. E., and Dunsmore, K. M. 1990. Incidence and virulence of Puccinia graminis. f. sp. tritici on wheat and barley in Canada in 1989. Can. J. Plant Pathol. 12:424-427.

Huerta-Espino, J. 1992. Analysis of wheat leaf rust and stem rust virulence on a worldwide basis. Ph.D. thesis, University of Minnesota, St. Paul.

Jin, Y., Szabo, L. J., Pretorius, Z. A., Singh, R. P., Ward, R., and Fetch, T. J., Jr. 2008. Detection of virulence to resistance gene $S r 24$ within race TTKS of Puccinia graminis f. sp. tritici. Plant Dis. 92:923-926.

Jin, Y., Szabo, L. J., Rouse, M. N., Fetch, T. J., Jr., Pretorius, Z. A., Wanyera, R., and Njau, P. N. 2009. Detection of virulence to resistance gene Sr36 within the TTKS lineage of Puccinia graminis f. sp. tritici. Plant Dis. 93:367-370.

Knott, D. R., and Anderson, R. G. 1956. The inheritance of stem rust resistance in ten varieties of common wheat. Can. J. Agric. Sci. 36:174-195.

Kolmer, J. A., Dyck, P. L., and Roelfs, A. P. 1991. An appraisal of stem and leaf rust resistance in North American hard red spring wheats and the probability of multiple mutations in populations of cereal rust fungi. Phytopathology 81:237-239.

Kosambi, D. D. 1943. The estimation of map distances from recombination values. Ann. Hum. Eugen. 12:172-175.

Leonard, K. J. 2001. Stem rust: Future enemy? Pages 119-146 in: Stem Rust of Wheat, from Ancient Enemy to Modern Foe. P. D. Peterson, ed. American Phytopathological Society, St. Paul, MN.

Leonard, K. J., and Szabo, L. J. 2005. Stem rust of small grains and grasses caused by Puccinia graminis. Mol. Plant Pathol. 6:99-111.

Le Roux, J., and Rijkenberg, F. H. J. 1987. Occurrence and pathogenicity of Puccinia graminis f. sp. tritici in South Africa during the period 1981-1985. Phytophylactica 19:456-472.

Levine, M. N., Ausemus, E. R., and Stakman, E. C. 1951. Wheat leaf rust studies at St. Paul, Minnesota. Plant Dis Rep. Suppl. 199:3-17.

Luig, N. H. 1983. A Survey of Virulence Genes in Wheat Stem Rust, Puccinia graminis f. sp. tritici, Vol. 11. Advances in Plant Breeding, Verlag Paul Parey, Berlin.

Luig, N. H., and Watson, I. A. 1965. Studies on the genetic nature of resistance to Puccinia graminis var. tritici in six varieties of common wheat. Proc. Linn. Soc. N. S. W. 90:299-327.

McIntosh, R. A., Wellings, C. R., and Park, R. F. 1995. Pages 101-137 in: Wheat Rusts: An Atlas of Resistance Genes. CSIRO Publications, East Melbourne, Australia.

Nagarajan, S., Nayar, S. K., Bahadur, P., and Kumar, J. 1986. Wheat Pathology and Wheat Improvement. Azad Hind Stores, Chandigarh, India.

Olivera, P., Newcomb, M., Szabo, L., Rouse, M., Johnson, J., Gale, S., Luster, G., Hodson, D., Cox, J. A., Burgin, L., Hort, M., Gulligan, C. A., Patpour, M., Justesen, A. F., Hovmoller, M. S., Woldeale, G., Hailu, E., Hundie, B., Tadessa, K., Pumphrey, M., Singh, R. P., and Jin, Y. 2015. Phenotypic and genotypic characterization of race TKTTF of Puccinia graminis $\mathrm{f}$. sp. tritici that caused a wheat stem rust epidemic in southern Ethiopia in 2013-14. 2015. Phytopathology 105:917-928. 
Olivera, P. D., Jin, Y., Rouse, M., Badebo, A., Fetch, T., Jr., Singh, R. P., and Yahyaoui, A. 2012. Races of Puccinia graminis f. sp. tritici with combined virulence to $\mathrm{Srl3}$ and $\mathrm{Sr} 9 \mathrm{e}$ in a field stem rust screening nursery in Ethiopia. Plant Dis. 96:623-628.

Pretorius, Z. A., Singh, R. P., Wagoire, W. W., and Payne, T. S. 2000. Detection of virulence to wheat stem rust resistance gene Sr31 in Puccinia graminis f. sp. tritici in Uganda. Plant Dis. 84:203.

Roelfs, A. P., Casper, D. H., Long, D. L., and Roberts, J. J. 1991. Races of Puccinia graminis in the United States in 1989. Plant Dis. 75:1127-1130.

Roelfs, A. P., and McVey, D. 1979. Low infection types produced by Puccinia graminis f. sp. tritici and wheat lines with designated genes for resistance. Phytopathology 69:722-730.

Rouse, M. N., Nava, I. C., Chao, S., Anderson, J. A., and Jin, Y. 2012. Identification of markers linked to the race $\mathrm{Ug} 99$ effective stem rust resistance gene $\mathrm{Sr} 28$ in wheat (Triticum aestivum L.). Theor. Appl. Genet. $125: 877-885$.

Rouse, M. N., Nirmala, J., Jin, Y., Chao, S., Fetch, T.G., Jr., Pretorius Z. A., and Hiebert, C. W. 2014. Characterization of $\operatorname{Sr} 9 h$, a wheat stem rust resistance allele effective to Ug99. Theor. Appl. Genet. 127:1681-1688.

Rouse, M. N., Wanyera, R., Njau, P., and Jin, Y. 2011. Sources of resistance to stem rust race Ug99 in spring wheat germplasm. Plant Dis. 95:762-766.

Sears, E. R. 1966. Chromosome mapping with the aid of telocentrics. Pages 370-381 in: Proc. 2nd Int. Wheat Genet. Symp. Hereditas Suppl. Lund, Sweden.

Sears, E. R., Loegering, W. Q., and Rodenhiser, H. A. 1957. Identification of chromosomes carrying genes for stem rust resistance in four varieties of wheat. Agron. J. 49:208-212.
Singh, R. P., Hodson, D. P., Jin, Y., Lagudah, E. S., Ayliffe, M. A., Bhavani, S., Rouse, M. N., Pretorius, Z. A., Szabo, L. J., Huerta-Espino, J., Basnet, B. R., Lan, C., and Hovmøller, M. S. 2015. Emergence and spread of new races of wheat stem rust fungus: Continued threat to food security and prospects of genetic control. Phytopathology 105:872-884.

Stakman, E. C., Stewart, D. M., and Loeing, W. Q. 1962. Identification of physiologic races of Puccinia graminis var. tritici. U.S. Dep. Agric. Res. Serv. E-617.

Wang, S., Wong, D., Forrest, K., Allen, A., Chao, S., Huang, B., Maccaferri, M., Salvi, S., Milner, S., Cattivelli, L., Mastrangelo, A., Whan, A., Stephen, S., Barker, G., Wieseke, R., Plieske, J., International Wheat Genome Sequencing Consortium, Lillemo, M., Mather, D., Appels, R., Dolferus, R., Brown-Guedira, G., Korol, A., Akhunova, A., Feuillet, C., Salse, J., Morgante, M., Pozniak, C., Luo, M. C., Dvorak, J., Morell, M., Dubcovsky, J., Ganal, M., Tuberosa, R., Lawley, C., Mikoulitch, I., Cavanagh, C., Edwards, K., Hayden, M., and Akhunov, E. 2014. Characterization of polyploid wheat genomic diversity using a high-density 90,000 SNP array. Plant Biotechnol. J. 12: 787-796.

Wanyera, R., Kinyna, M. G., Jin, Y., and Singh, R. P. 2006. The spread of stem rust caused by Puccinia graminis f. sp. tritici, with virulence on $\mathrm{Sr} 31$ in wheat in eastern Africa. Plant Dis. 90:113.

Watson, I. A., and Stewart, D. M. 1956. A comparison of the rust reaction of wheat varieties Gabo, Timstein, and Lee. Agron. J. 48:514-516.

Zwer, P. Z., Park, R. F., and McIntosh, R. A. 1992. Wheat stem rust in Australia 1969-1985. Aust. J. Agric. Res. 43:399-431. 